\title{
A Review of the Linkages between Climate Change, Agricultural Sustainability and Poverty in Malaysia
}

\author{
Chamhuri Siwar \\ Professor \\ Institute for Environment and Development (LESTARI) \\ Universiti Kebangsaan Malaysia \\ Selangor Darul Ehsan, Malaysia \\ Tel: +603-8921 4154 \\ E-mail: csiwar@ ukm.my; \\ Md. Mahmudul Alam \\ MSc Student \\ Institute for Environment and Development (LESTARI) \\ Universiti Kebangsaan Malaysia (UKM) \\ Selangor Darul Ehsan, Malaysia \\ Tel: +601-6279 9091 \\ E-mail: rony000@gmail.com \\ MD. Wahid Murad \\ Senior Lecturer \\ Department of Economics \\ University of Malaysia Terengganu \\ Terengganu, Malaysia \\ Tel: +609-668 4152 \\ E-mail: mwmurad@gmail.com \\ Abul Quasem Al-Amin \\ PhD Researcher \\ Institute for Environment and Development (LESTARI) \\ Universiti Kebangsaan Malaysia (UKM) \\ 43600 UKM Bangi, Selangor Darul Ehsan, Malaysia \\ Tel: +603-8921 4161 \\ E-mail: amin_cant@yahoo.com
}

\section{Citation Reference:}

Siwar, C., Alam, M.M., Murad, M.W., and Al-Amin, A.Q. 2009. A Review of the Linkages between Climate Change, Agricultural Sustainability and Poverty in Malaysia, International Review of Business Research Papers, Vol. 5(6), pp. 309-321. (online) http://www.bizresearchpapers.com/23.\%20Siwar.pdf

This is a pre-publication copy.

The published article is copyrighted by the publisher of the journal. 


\title{
A Review of the Linkages between Climate Change, Agricultural Sustainability and Poverty in Malaysia
}

\author{
Chamhuri Siwar**, Md. Mahmudul Alam*, Md. Wahid Murad ${ }^{\dagger}$, Abul Quasem Al- \\ Amin
}

\begin{abstract}
The issues of climate change, agricultural sustainability and poverty in Malaysia are found to have been connected one with other in an interesting and circular way. The quantitative determination of the linkages between these three factors is certainly a difficult task, which is beyond the scope of the present study. This study is thus primarily aimed at reviewing the linkages between climate change, agricultural sustainability and poverty in Malaysia. Some issues requiring further investigation in order to clearly understand the linkages between climate change, agricultural sustainability and poverty have been suggested. These have been developed with particular reference to appraisals concerned with the development and implementation of social policy, programmes and practices relevant to these three issues. The study closes with some concluding remarks.
\end{abstract}

Field of Research: Development Economics, Environmental Economics, Agricultural Economics

\section{Introduction}

The economies of least developed countries and many developing countries are still dependent on agriculture. These countries spend a lion's share of their expenditures for purchasing food. Agricultural sector, however, in these countries has got much attention recently from both pundits and common people alike amid soaring global food crisis in 2008. Under the present circumstances, even developed countries including the United States of America and the European Union are also emphasizing much on the agriculture sector. The agricultural sector has gone through an enormous evolution over the past decades when many new ideas were implemented and many new technologies were introduced. Producing more food for higher demand had became a continuous challenge around the globe, leading to food security problems in

\footnotetext{
"Chamhuri Siwar, Professor, Institute for Environment and Development (LESTARI), Universiti Kebangsaan Malaysia, 43600 UKM Bangi, Selangor Darul Ehsan, Malaysia, E-mail: csiwar@ ukm.my; Tel: +603-8921 4154.

${ }^{*}$ Md. Mahmudul Alam, MSc Student, Institute for Environment and Development (LESTARI), Universiti Kebangsaan Malaysia, 43600 UKM Bangi, Selangor Darul Ehsan, Malaysia, E-mail: rony000@gmail.com; Tel: +601-6279 9091.

${ }^{\top}$ Md. Wahid Murad, Senior Lecturer, Department of Economics, University of Malaysia Terengganu, Terengganu, Malaysia, E-mail: mwmurad@gmail.com, Tel: +609-668 4152.

${ }^{\ddagger}$ Abul Quasem Al-Amin, Post-Doc Research fellow, Institute for Environment and Development (LESTARI), Universiti Kebangsaan Malaysia, 43600 UKM Bangi, Selangor Darul Ehsan, Malaysia, E-mail: amin cant@yahoo.com; Tel: +603-8921 4159.
} 
the medium and long terms. In the late 1960s and early 1970s it was assumed that the growth of agricultural production would be unable to meet the world demand, but in the mid 1970s world food production grew rapidly by using various newly introduced farming methods. Since the late 1980s, however, high food production raised new threat due to depletion of environmental and natural resources and land degradation (United Nations 1997). Considering these facts, the concept of sustainable agricultural development and international food security has got priority (Lancker and Nijkamp 2000, Nijkamp 1999).

While prioritizing the sustainable agriculture, it was found that climate change played a major role in determining crop performance. The climatic factors as expressed by the amount of rainfall, sunshine hours, temperature, relative humidity and length of the drought period result in year-to-year variability of crop production. Climate change is one of the major potential threats to national food security and sustainable agriculture for a country. As the change of climate is a continuous and long term process, its impacts will continue for long successive years and finding out its remedy will also be a very time consuming process.

In fact, the concept of climate change has both positive and negative impacts on agricultural sustainability of a country, where sustainable agriculture affect agricultural productivity, food security, technology, and environment which have different components, with varying priorities in global and regional levels. There are many empirical works to measure agricultural sustainability through use of diverse indicators, but few are on the impact of climate change. In this paper we try to draw attention on these resources in arriving at a theoretical framework for deriving a core set of indicators of agricultural sustainability and integrate them.

\section{Concept of Sustainability and Agricultural Sustainability}

The general description of sustainable development in the Brundtland Report (WCED 1987 ) is that it is a means of meeting the needs of the present without compromising the ability of future generations to meet their own needs. The Food and Agricultural Organization (FAO) of the United Nations provides a specific description of sustainable agricultural development where the usage of resources and environmental management are combined with increased and sustained production, secured livelihoods, food security, equity, social stability and people's participation in the development process is considered in a development path. If these conditions can be fulfilled, sustainable agricultural development will be environmentally non-degrading, technically appropriate, economically viable and socially acceptable. Therefore, the optimum welfare of the present and future can be achieved through a co-evolutionary strategy focused on economic, environmental and social objectives with agricultural production (Pearce and Atkinson, 1995).

The issue of sustainable development has gained much attention and different concepts of sustainability have been developed by different groups. Based on policy options and action-oriented concept to solve environmental change issues, sustainable industry, sustainable tourism or sustainable transport (Bergh 1996), sub-global spatial units like sustainable regions or sustainable cities (Giaoutzi and Nijkamp 1994, Nijkamp and Perrels 1994), global impacts which lead to global environmental issues (Cline 1992, Fankhauser 1995), the distinction between strong and weak sustainability 
essentially means different categories of land use (Pearce and Turner 1990, Pelt 1995) was developed. The dilemma here is how the land will be used for different sectors like agriculture, industry, tourism etc. and how to optimize the economic performance and how to compensate usage of land for various competing sectors. Even within the agricultural sector, where it is not possible to use the same land simultaneously there are various competing sub-sectors like cereal crop production, livestock, cash crop production etc (Barnett and Payne 1995), and even for different types of intervention such as, use of pesticides, herbicides, etc. (Douven 1997, Simmons 1997).

In a survey a series of research priorities on socio-economic aspects of land use and climate change were identified by Ierland and Klaassen in 1996. Some of these issues are long term and related to national or international security such as, soil erosion, chemical poisoning or nuclear waste (Daly and Cobb 1990); some issues are related to daily quality of life such as, water pollution, shortage of food or resources (HomerDixon 1992). The combined effects of these issues are difficult to predict such as, natural and environmental catastrophes in recent times- floods, landslides, long periods of drought etc (United Nations 1997). Latter studies examined vulnerability defined in terms of yield, farm profitability, regional economy and hunger explicitly considering uncertainty about future climate-change impacts (Reilly, 1999; Schimmelpfenning et al., 1996).

From ancient times in the history of economic thought, varying attention has been given to land as an important economic production factor. In the neoclassical theory productivity and welfare differences between regions explained by soil conditions of different areas means land assumed mainly a functional economic place (Giaoutzi and Nijkamp 1994). With the emergence of ecological economics, the use of land again getting more attention from economists and policymakers (Bergh 1996). In addition, soil condition has a variety of direct and indirect impacts on the quality and resilience of ecosystems which has global impacts on biodiversity (Douven 1997). As a consequence, soil management has become an important policy task in many countries where it aims at improving the soil condition by utilizing the land at its optimum level for various agricultural sub-sectors. For example, a same piece of land can be used for both cereal crops and cash crops all round the year based on the season and crop patterns so that planned cultivation on a piece of land reduces soil erosion and increases fertility of a land.

According to experts, sustainability indicators are quantifiable and measurable attributes of a system (Panell and Schilizzi 1999). Sustainable agriculture meets current and long-term needs for food, fibre, and other related needs of society (Tilman et al. 2002). One set of suggested indicators, that USDA uses to assess agricultural sustainability at farm and regional levels, is based on six measurable variables- yield, profit, frequency of crop failure, soil depth, organic carbon and permanent ground cover (Gomez et al. 1996). Another set of five basic attributes for indicators of agricultural sustainability are: productivity, stability (internal factor), reliability, resilience and adaptability (external factors) (Lopez-Ridaura 2005).

There is no universal definition for the concept of sustainable agriculture among economists and practitioners. The concept of sustainable agriculture is still evolving. While green-revolution agriculture concept of mid twentieth century addressed mainly productivity issues, sustainable agriculture system address productivity issues 
beyond mere intensively, but keeps into consideration multidimensional concerns of sustainability in sight like economic, environmental and social concerns. According to different existing literature, there are many important elements of agricultural sustainability, such as, soil fertility, soil loss, topsoil depletion, soil conservation methods- including strip cropping, reduced tillage and no-till, prevent loss of soil due to wind and water erosion, water conservation and protection, improve the quality of drinking and surface water, groundwater contamination, protect wetlands, growing plants - rye, clover or vetch after harvesting a grain, intercropping, growing variety of crops and livestock to reduce risks from extremes in weather, pest management, wildlife habitat and increased populations of beneficial insects, intensive grazing systems with high-quality forage and reduced feed costs, animal selection, reproduction, hard health, confined livestock production, nutrients of food and livestock, managing of manure, nitrogen and other plant nutrients and reduces purchased fertilizer costs, agro-forestry, wildlife diversity, decline of family farms, living and working conditions for farm labourers, increasing costs of production, the disintegration of economic and social conditions in rural communities, long term yield, long term profitability, contribution to community, product value, social/human capital, local economy, social and political context of food and agricultural policy, land ethics- long-term good of all members of the land community, land use, labour, rural community development, consumers and the food system, market conditions, innovative marketing strategies of selling at or through the World Wide Web, direct marketing to farmers markets, roadside stands, restaurants and small grocers, running community-supported agriculture (CSA) enterprises, rate of environmental degradation, prudent use of renewable and recyclable resources etc.

\section{Linkages between Climate Change, Agricultural Sustainability and Recent Food Crisis}

Since the beginning of the 1980s, many climatologists predicted significant global warming in the coming decades due to increasing atmospheric concentration of carbon dioxide and other trace gases. In 1988 the Intergovernmental Panel on Climate Change (IPCC) was established by the United Nations Environmental Programme (UNEP) and the World Meteorological Organization (WMO) to assess the scientific, technical and socioeconomic information relevant for the understanding of human induced climate change, its potential impacts and options for mitigation and adaptation. Major possible changes in atmospheric, soil and hydrological regimes were forecasted to occur with a direct impact on food supply and demand.

Food security was the main issue in earlier 1990s (Kane et al., 1992) and the investigation was generally focused on regional or domestic agricultural impact (Adams et al., 1990; Mooney and Arthur, 1990). The recognition of the global nature of climate change and of the interdependencies between economies led successively to various attempts to introduce international trade into the picture (Rosenzweig et al., 1993; Reilly, 1994; Fischer et al., 1993; Adams et al., 1990). Farmers' response to the climate and natural environmental change was thus taken into account (Mendelsohn 1994, 1999, Reilly 1994, Adams et al., 1988, 2000). Finally, Sustainable agricultural development has caught up attention of economists and experts rapidly after the United Nations Conference on Environment and Development in Rio de Janeiro in 1992. Earlier when the Brundtland Report published in 1987 it was recognized that a 
greater commitment to environmental protection and sustainable development was needed because of the use of natural resources and the rise in pollution.

The recent crisis of rice (2007-2008) all over the world showed a very good indication about the necessity of monitoring agricultural sustainability on regular basis. Due to this acute food crisis all over the world, many countries have been forced to reconsider the issue of agricultural sustainability and high rates of production, which have strong interactive impacts on climate change. This activity also forces us to develop an appraisal system to monitor the state of sustainable economic system from time to time.

\section{WORLD FOOD CRISIS}

Sept. 7, 2007:Vietnam, the world's third- biggest rice exporter, restricts rice exports to slow inflation.

Dec. 4, 2007: Argentina temporarily restricts grain exports.

Jan. 1, 2008: China, the world's biggest grain producer, starts to curb overseas sales of wheat, corn and rice by issuing export permits.

Jan. 19, 2008: Egypt bans rice exports.

Feb. 8, 2008: The American Bakers Association asks the U.S. Department of Agriculture to curb wheat exports.

Feb. 27, 2008: At least four people are killed during three days of protests over high commodity prices in Cameroon.

March, 2008: Philippines authorities begin to crack down on hoarders.

March 17, 2008: India halts all exports of non-basmati rice. It also extends an existing export ban on crops such as peas and beans.

March 28, 2008: Vietnam extends rice export restrictions.

April 4, 2008: Haitians riot over rising food prices. At least three people are killed.

April 6, 2008: Egyptians riot over rising food prices.

April 9, 2008: Corn commodities on the Chicago Board of Trade reach a record $\$ 6.16$ a bushel.

April 12, 2008: Police clash with 10,000 workers in Bangladesh who smashed vehicles and attacked factories, demanding higher wages to pay for food. The Haitian prime minister is forced to step down in an attempt to defuse anger over food prices. A U.N. police officer bringing food to his unit in Port-au-Prince is killed.

April 14, 2008: U.N. Secretary-General Ban Ki-moon says that a global food crisis has reached "emergency proportions." The World Bank has forecasted that 33 nations from Mexico to Yemen may face social unrest.

April 16, 2008: Malawi plans to restrict corn exports.

April 17, 2008: Kazakhstan, the world's sixth-largest wheat exporter, bans wheat exports between April 27 and Sept.1.

April 18, 2008: India permits rice exports to Bhutan. Indonesia, the world's third-largest rice producer, says it will hold back surplus rice.

April 21, 2008: Thailand, the world's largest rice exporter, is under pressure to restrict exports.

Source: World food crisis hits home:

http://www.seattlepi.com/business/360096_foodshortage23.html

Agricultural system affects the environment, but interestingly the agricultural system is also affected by the changes in environment and climate conditions (Socolow 1999, Alexandratoss 1999, Tilman et al. 2002). Adding to this, a sudden natural disaster can have a severe negative impact on the overall agricultural sustainability. These disasters increase global demand for food and countries struggle to meet domestic food demands. International collaboration is essential in these situations. Keeping this in mind, from our view point, international collaboration is also required to be incorporated in sustainable agriculture system. Not only does the sustainable agriculture system address mlany environmental and social concerns, but it also may offer innovative and economically viable opportunities for farmers, labourers, 
consumers, policymakers and many others in the entire food system and the economic system.

\section{Impacts of Climate Change on Malaysian Agriculture}

The aggregate effect of climate change on agricultural production is proven small to moderate depending on the regional position. This regional variation has results in overall decrease in agriculture yields and productivity. Malaysia is not an exception of that (NRS, 2001). Malaysian grains production has been in risk due to climate variability, seasonal rainfall uncertainty, temperature fluctuations and degradation of efficiency, insects and diseases infections to seeds. Together with this effect of climate on pests has added to the effect of other factors and made agricultural syndrome outbreaks.

The impact on agriculture especially on rice production has been subjected to many scientific researches during the last two decades (Tilman et al. 2002; Socolow 1999; Alexandratoss 1999; Reilly, 1999; Singh et al. 1996; Penning de Vries, 1993). The scientific evidence is now well established in Malaysia. Generally the average potential yield of rice varies is about 10 tons $\mathrm{ha}^{-1}$ in the tropics and over 13 tons ha $\mathrm{ha}^{-1}$ in temperate region but the actual farm yields in Malaysia vary from 3-5 tons ha $^{-1}$ (AlAmin and Siwar, 2008). The more scientific evidence can be found by the previous studies of Singh et al. 1996; Penning de Vries, 1993; Yoshida, 1981. However they used different methodology also in their approaches but the evident is that within the critically high temperature, the rate of ripening efficiency is negative. The changes in temperature with unexpected rainfall patterns is projected to negative which shows moderate effects in the Malaysian future mass grains production (Singh et al. 1996; Penning de Vries, 1993; Al-Amin and Siwar, 2008).

One other factor has been accompanied to the agriculture production is the increase in atmospheric $\mathrm{CO}_{2}$ concentration (Penning de Vries, 1993). The development rates of agriculture crop however accelerate in response to an increase in $\mathrm{CO}_{2}$ concentration from $160 \mathrm{ppm}$ (parts per million) to $900 \mathrm{ppm}$ with standard temperature $\left(<35^{\circ} \mathrm{C}\right)$. But the increasing temperature above the tolerance limit $\left(>26^{\circ} \mathrm{C}\right)$ and $\mathrm{CO}_{2}$ variation reduces the photosynthesis, increase the respiration and shorten the vegetation and grain-filling periods and ultimately decreases the overall Malaysian agriculture yields. Tashiro and Wardlaw, (1989) found that current climate change scenario under different future temperature above $25^{\circ} \mathrm{C}$, declines grain mass of $4.4 \%$ and food grain yield may decline as much as $9.6-10 \%$ per $1{ }^{\circ} \mathrm{C}$ rises in temperature. It is evident that the average response to an increase of potential yields of about $10 \mathrm{~kg} / \mathrm{ha} / \mathrm{ppm} \mathrm{CO}_{2}$ or about $15 \mathrm{~kg} / \mathrm{ha} / \mathrm{ppm} \mathrm{CO}_{2}$. It is obvious that the negative effects occur in agriculture due to unexpected weather pattern (Penning de Vries, 1993). Similar result found by Ziska et al. (1997) and they revealed that the grain-filling periods are markedly affected by an increase in temperature above the present ambient level.

We may wrap up that unexpected climate change or warmer temperature trends have had a significant impact on Malaysian crop yields. Previous modelling studies have also contributed to predict the changes in agriculture. The studies by Al-Amin and Siwar, (2008); Tilman et al. (2002); Socolow (1999); Alexandratoss (1999); Reilly, (1999); Schimmelpfenning et al., (1996); Singh et al. (1996); Penning de Vries, (1993) are the prime empirical evidences. However we find necessity to observed 
sensitivity of previous studies and presents need to synthesize crop production and rigorous climate change substantiation to date information which perhaps sorts detailed accurate prediction, to provide critically future agriculture adaptation projection and policy options.

\section{Climate Change Vulnerability and Poverty in Malaysia}

Climate change is one of the most challenging threats that facing Malaysia with the whole world now. The most severe consequences include shortage of rainfall (i.e. $<\mathrm{mm} /$ day downpours), high temperature $\left(>26^{\circ} \mathrm{C}\right)$ and unpredicted weather (i.e. variations and fluctuations of summer and monsoon seasons). Malaysian economy is more vulnerable because of its lacking to adaptive capacity within the economy and proper policy relevant appropriate technical foundations (Al-Amin and Siwar, 2008). The quantitative relationship between climate change and poverty vulnerability is yet absence in Malaysia. No correlation had been found so far to single out poverty map due to climate change. Sometimes the poverty incidence and quantification of projection are not apparent for Malaysia. However according to some scientific researchers (i.e. Ebi et al. 2006; Haines et al. 2006; Confalonieri, et al. 2007) even where the impacts of climate change and poverty incidence are not yet obvious, scenarios of future projection, quantification of estimation can justify capacity building which ensuring the correlation responses between future agricultural sustainability and its net benefits into long run economic planning. The recent studies by WHO, (2003); Lemmen and Warren, (2004); Haines et al. (2006); Ebi et al. (2006) and Confalonieri, et al. (2007) revealed that the actual and virtual vulnerability to climate change depends on various factors and future projections, major of them are as follows:

- economic development condition

- income level and distribution

- food availability

- population density

- local environmental condition

- geographical position

- quality and availability of public health care provision.

There are many other cases that found correlation with climate change and large uncertainties and exhibit large variation across regions to regions. The vulnerability to climate change also defers due to economic development and geographical position (i.e. variations of summer and monsoons), demographic subgroups but overall the most affected groups are children, elderly people, indigenous populations, chronically ill people, people with a low income and coastal communities (Lemmen and Warren, 2004; Ebi et al. 2006; Confalonieri, et al. 2007). Without hunger importance (HI) ranking with poverty map, the general appearances of rainfall fluctuation and temperature rise evidence to climate change on poverty could misinterpret the relationship between climate change and poverty vulnerability, many of which have not been included in the climatic impact assessments indeed. However, future climate change projections on the poorest states in Peninsular Malaysia by National Hydraulic Research Institute of Malaysia (NAHRIM, 2006) may facile the mainstreaming adaptation planning and options for possible poorest regions in ad-hoc basis (Table 1: 
Maximum monthly values of two climate factors i.e. temperature and rainfall in the selected regions).

NAHRIM (2006) also demonstrates the possible vulnerable states based on temperature fluctuations up to year 2050. The empirical downscaling scenario projections make use of the quantitative relationships between the state of the larger scale climatic environment and adaptation policy. By coupling specific baseline climate projection, it provides a valuable outcome between climate model projections and the policy investigation. In the long term, climate change is to be an additional problem that agriculture faces in meeting national food requirements. Since it is likely that some climate change will occur over the next 50-100 years (NRS, 2001), adaptation options has been primarily suggested as the means to reduce the impact of climate change on Malaysia and empirical analysis and quantitative modelling of adaptation are gaining in importance in studies of climate change impacts on Malaysian economy.

Table 1: Climate Change Projections in Malaysia by 2050

\begin{tabular}{|c|c|c|}
\hline \multirow[t]{2}{*}{ Regions/Sub-regions/states } & \multicolumn{2}{|c|}{$\begin{array}{l}\text { Projected Change* in Maximum Monthly } \\
\text { Value }\end{array}$} \\
\hline & Rainfall (\%) & $\begin{array}{c}\text { Temperature } \\
\left({ }^{0} \mathrm{C}\right)\end{array}$ \\
\hline $\begin{array}{l}\text { North East Region -Terengganu, Kelantan, Northeast- } \\
\text { coast }\end{array}$ & +32.8 & +1.88 \\
\hline Central Region-Klang, Selangor, Pahang & +8.0 & +1.38 \\
\hline North West Region-Perlis (west coast), Perak, Kedah & +6.2 & +1.80 \\
\hline Southern Region-Johor, Southern Peninsula & +2.9 & +1.74 \\
\hline
\end{tabular}

* Difference $=$ Average 2025-2034 and 2041-2050 minus Average 1984-1993

Source: NAHRIM, 2006

Table 2: Most Vulnerable States: Hardcore Poverty and Climate Change by 2050.

\begin{tabular}{|l|c|c|c|c|}
\hline States & $\begin{array}{c}\text { Household } \\
\text { Size }\end{array}$ & $\begin{array}{c}\text { Hardcore Poverty } \\
\text { Incidence }(\%)\end{array}$ & $\begin{array}{c}\text { Projected } \\
\text { Rainfall Change } \\
(\%)\end{array}$ & $\begin{array}{c}\text { Projected } \\
\text { Temperature } \\
\text { Change }\left({ }^{0} \mathrm{C}\right)\end{array}$ \\
\hline Terengganu & 5.0 & 4.4 & +32.8 & +1.88 \\
\hline Kelantan & 5.2 & 1.3 & +32.8 & +1.88 \\
\hline Kedah & 4.6 & 1.3 & +6.2 & +1.80 \\
\hline Perak & 4.1 & 1.1 & +6.2 & +1.80 \\
\hline Perlis & 4.2 & 1.7 & & +1.80 \\
\hline
\end{tabular}

Source: NAHRIM, 2006, Ninth Malaysia Plan, 2006.

\section{Conclusion}


The climate change impacts on agricultural sustainability varies from developed economy to developing economy, economic condition of country to country, region to region and time to time. The effect on agricultural crops in Malaysia governs by the timing of physiological process, the rate of spreading out and survival reproductive structures and evaporation function due to climate change. Increases in warmth affect the moisture availability through effects on evaporation; in general evaporation increases by about $5 \%$ for each $1{ }^{\circ} \mathrm{C}$ increase in main annual temperature. Climate change is expected to result in long-term water and other resource shortages also which would be worsening soil condition, disease and pest outbreaks on crops and livestock, sea-level rise, and so on. Vulnerable areas are expected to experience losses in agricultural productivity, primarily due to reductions in crop yields and ultimate effect goes much on poor. So, climate change is a major threat for sustainable agriculture for Malaysia.

Based on the primary projections and impacts; proper and appropriate policies are required to aim at improving adaptation to climate change that are likely indicate alteration from more priority measures such as through the identification of climate risk hot spots and prioritization loom. The two components are to be clear to any prioritization approach: (i) evaluate the poorest region and future poverty map due to climatic factors and (ii) adaptation alteration by the governing body (i.e. Govt.) based on the future agricultural sustainability, rainfall fluctuation, temperature, and crop yield critical issues. As climate is continuously changing and affecting the agriculture in diversified ways, a good measurement of its impacts on sustainable agriculture and smooth adaptation are needed to ensure long run agricultural sustainability in Malaysia.

\section{Acknowledgements}

The previous comments and suggestions for the draft manuscript from $9^{\text {th }}$ International Business Research Conference in Australia, 2008 and $2^{\text {nd }}$ MARDI conference JB Malaysia, 2009 are duly acknowledged.

\section{Reference:}

Adams, R. M., Chen, C. C., McCarl, B. A., and Schimmelpfenning, D. E. 2001. "Climate Variability and Climate change: Implications for Agriculture. In The Long Term Economics of Climate Change", in Hall, D. C. and Howarth, R. B. (Eds.), Advances in the Economics of Environmental Resources, Emerald Group Publishing Limited, Vol. 3, pp. 95-113.

Adams, R. M., Glyer, J. D., McCarl, B. A., and Dudek, D. J. 1988. "The Implications of Global Change for Western Agriculture", Western Journal of Agriculture Economics, vol. 13, pp. 348-356.

Adams, R. M., Rosenzweig, C., Peart, R. M., Ritchie, J. T., McCarl, B. A., Glyer, J. D., Curry, R. B., Jones, J. W., Boote, K. J., and Allen, Jr. L. H. 1990. "Global Climate Change and U.S. Agriculture", Nature, vol. 345, pp. 219-224.

Al-Amin, A. Q. and Siwar, C. 2008. "The economic dimensions of climate change: impacts and adaptation practices in Malaysia", Proceedings of the 9th 
International Business Research Conference, Novotel Hotel, Melbourne, Australia, 24-26 November.

Alexandratoss, N. 1999. "World food and agriculture outlook for the medium and longer term", Proceedings of the National Academy of Sciences, vol 96, pp. 5908-5914.

Barnett, V., Payne, R., and Steiner, R. (eds.) 1995. Agricultural Sustainability, John Wiley, New York.

Bergh, J. C. J. M. Van den 1996. Ecological Economics and Sustainable Development, Edward Elgar, Cheltenham.

Cline W. R. 1992. The Economics of Global Warming, Institute for International Economics, Washington, D. C.

Confalonieri, U., Menne, B., Akhtar, R., Ebi, K.L., Hauengue, M., Kovats, R.S., Revich, B. and Woodward, A. 2007. "Human health Climate Change 2007: Impacts, Adaptation and Vulnerability", in Parry, M. L., Canziani,O. F., Palutikof, J. P., Linden, P. J. van der and Hanson, C. E. (Eds.), Fourth Assessment Report of the Intergovernmental Panel on Climate Change, pp. 391-431, Cambridge University Press, UK.

Daly, H., and Cobb, J. 1990, For the Common Good, Green Print Publishing, London.

Douven, W. 1997. "Improving the Accessibility of Spatial Information for Environmental Management", Ph. D. Dissertation, Faculty of Economics, Free University, Amsterdam.

Ebi, K. L., Kovats, R. S., and Menne, B. 2006. "An Approach for Assessing Human Health Vulnerability and Public Health Interventions to Adapt to Climate Change", Environ Health Perspectives, vol. 114, pp. 1930-1934.

Fankhauser, S. 1995. Valuing Climate Change - The Economics of the Greenhouse, Earthscan, London.

Fischer, G., Frohberg, K., Parry, M. L., and Rosenzweig, C. 1993. "Climate Change and World Food Supply, Demand and Trade," in Kaya, Y. et al. (Eds.), Costs, Impacts, and Benefits of CO2 Mitigation, pp. 133-152.

Giaoutzi, M., and Nijkamp, P. 1994. Decision Support Models for Regional Sustainable Development, Avebury, Aldershot, UK.

Gomez, A. A., Kelly, D. E., Syers, J. K. and Coughlan, K. J. 1996. "Measuring the sustainability of agricultural systems at the farm level", Doran, J. W., Jones, A. J. (Eds.), Methods of Assessing Soil Quality, SSSA Special Publication.

Haines, A., Kovats, R.S., Campbell-Lendrum, D. and Corvalan, C. 2006. "Climate change and human health: Impacts, vulnerability and public health", Public Health, vol. 120, pp. 585-596.

Homer-Dixon, T. 1992. "Environment al Change and Acute Conflict", International Security, vol. 16, no. 2, pp. 31-102.

Ierland, E.C., and Klaassen, M. 1996. "Socio-Economic Impacts and Climate Change", in Kok, M. (Ed.), Environmental Security and Sustainable Development, RIVM Report no. 461502012, Bilthoven, pp.156-172.

Kane, S., Reilly, J. M., and Tobey, J. 1992. "An Empirical Study of the Economic Effects of Climate Change on World Agriculture", Climatic Change, vol. 21, pp. 17-35.

Lancker, E., and Nijkamp, P. 2000. "A Policy Scenario Analysis of Sustainable Agricultural Development Options: a case study for Nepal", Impact assessment and Project Appraisal, vol. 18, no. 2, pp. 111-124.

Lemmen, D. S. and Warren, F. J. 2004. Climate Change Impacts and Adaptation: A Canadian Perspective. A Report of the Government of Canada's Climate 
Change Impacts and Adaptation Program. Retrieved: 30 April 2009, from http://adaptation.nrcan.gc.ca/perspective_e.asp

Lopez-Ridaura, S., Keulen, H. V., Van Ittersum, M. K. and Lefelaar, P. A. 2005. "Multiscale methodological framework to derive criteria and indicators for sustainability evaluation of peasant natural resources management systems," Development and Sustainability, vol 7, pp.51-69.

Mendelsohn, R. O., Nordhaus, W. D., and Shaw, D. 1994. "The Impact of Global Warming on Agriculture: A Ricardian Analysis", American Economic Review, vol. 84, no. 4, pp. 753-771.

Mendelsohn, R. O., Nordhaus, W. D., and Shaw, D. 1999. "The Impact of Climate Variation on U.S. Agriculture," in Mendelsohn, R. O. and Neumann, J. E. (Eds.), The Impact of Climate Change on the United States Economy, Cambridge University Press, Cambridge, pp. 55-74.

Mooney, S. and Arthur, L., 1990. "The Impacts of Climate Change on Agriculture in Manitoba, Canadian Journal of Agricultural Economics, vol. 38, pp. 685-94.

NAHRIM. 2006. "Final Report: Study of the Impact of Climate Change on the hydrologic Regime and Water Resources of Peninsular Malaysia", National Hydraulic Research Institute of Malaysia (NAHRIM) and California Hydrologic Research Laboratory (CHRL).

Nijkamp, P. 1999. "Environmental Security and Sustainability in Natural Resource Management", in Lonergan, S. C. (Ed.), Environmental Change, Adaptation and Security, Kluwer, Dordrecht.

Nijkamp, P., and Baaijens, S. 1999. "Explanatory Meta-analysis of Tourist Expenditures", Journal of Policy Modeling, vol. 22 no.7, pp.821-855.

Nijkamp, P., and Perrels, A. 1994. Sustainable Cities in Europe, Earthscan, London.

Ninth Malaysia Plan. 2006. "Ninth Malaysia Plan 2006-2010", The Economic Planning Unit, Prime Minister's Department, Putrajaya, Malaysia.

NRS. (National response strategies to climate change) 2001. Ministry of Science, Technology and the Environment, Malaysia.

Panell, D. J., and Schilizzi, S. 1999. "Sustainable agriculture: a matter of ecology, equity, economic efficiency or expedience", Journal of Sustainable Agriculture, vol. 13, pp. 57-66.

Pearce, D. W. and Turner, K. 1990. Economics of Natural Resources and the Environment, Harvester-Wheatsheaf, London.

Pearce, D. W., and Atkinson, G. 1995. "Measuring Sustainable Development", Ecodecision, no. 9 (June), pp. 64-66.

Pelt, M. J. F. V. 1995. Ecological Sustainability and Project Appraisal, Avebury Aldershot, UK.

Penning de Vries, F. W. T.,1993. "Rice production and climate change", Penning de Vries, F. W. T., Teng and Metselaar, K. (Eds.). System approaches for agricultural development, IRRI, Kluwer.

Reilly, J. 1999. “Climate Change: Can Agriculture Adapt?”, Choices, vol. 14, no. 1, pp. 4-8.

Reilly, J. M. 1994. "Crops and Climate Change”, Nature, vol. 367, pp. 118-119.

Rosenzweig, M. R. and Binswanger, H. P. 1993. "Wealth, Weather Risk and the Composition and Profitability of Agricultural Investments", Economic Journal, vol. 103, pp. 56-78.

Schimmelpfenning, D. 1996. "Uncertainty in Economic Models of Climate Change Impacts", Climatic Change, vol. 33, no. 2, pp. 213-34. 
Simmons, P.J. (Ed.) 1997. Environmental Change and Security Project Report, The Woodrow Wilson Center, Washington D.C.

Singh, S., Amartalingam, R., Wan Harun, W. S., Islam, M. T. 1996. "Simulated impact of climate change on rice production in Peninsular Malaysia", Proceedings of the National Conference on Climate Change. 12-13 August, UPM, Malaysia, pp. 41-49.

Socolow, R. H. 1999. "Nitrogen management and the future of food: lessons from the management of energy and carbon", Proceedings of the National Academy of Sciences, vol. 96, pp. 6001-6008.

Tashiro, T., and Wardlaw, I. F. 1989. "A comparison of the effect of high temperature on grain development in wheat and rice," Annals of Botany, vol. 64, pp. 5965.

Tilman, D., Cassman, K. G., Matson, P., Naylor, R. and Polasky, S. 2002. "Agricultural sustainability and intensive production practices", Science, vol. 418, pp.671-676.

United Nations. 1997. Critical Trends: Global Changes and Sustainable Development, UN Department for Policy Coordination and Sustainable Development, New York.

WCED. 1987. Our Common Future, Oxford University Press.

WHO. 2003. "Methods of Assessing Human Health Vulnerability and Public Health Adaptation to Climate Change", Series No. 1: Health and Global Environmental Change. WHO Regional Office for Europe, Denmark.

Yoshida, S. 1981. Fundamentals of rice crop science, International Rice Research Institute, Los Banos, Philippines.

Ziska, L. H., Namuko, O., Moya, T., and Quilang, J. 1997. "Growth and yield response of field-grown tropical rice to increase $\mathrm{CO} 2$ and air temperature", Agronomy Journal, vol. 89, pp. 45-53. 